\title{
PERAN DINAS LINGKUNGAN HIDUP KOTA SURABAYA DALAM PENGENDALIAN PENCEMARAN AIR SUNGAI BRANTAS
}

\author{
Martika Dini Syaputri \\ Staf Pengajar Fakultas Hukum Universitas Katolik Darma Cendika Surabaya \\ Korespondensi: dini.martika@gmail.com
}

\begin{abstract}
Abstrak
Kondisi sungai Brantas Kota Surabaya semakin memprihatinkan akibat pencemaran dari limbah rumah tangga maupun limbah industri. Sebagai pemasok bahan baku PDAM, kualitas sungai Brantas harus diperhatikan sehingga tidak menimbulkan kerugian bagi masyarakat pengguna air. Letak sungai yang berada di kawasan hilir menjadikan beban pencemaran yang dialami sungai Brantas semakin berat serta lemahnya pengawasan dan penegakan hukum juga ikut mempengaruhi penurunan kualitas air sungai Brantas. Penelitian ini dilakukan untuk menunjukkan peran strategis Dinas Lingkungan Hidup Kota Surabaya dalam pengendalikan pencemaran air sungai Brantas baik dalam pengeluaran izin, pengawasan, pemberian sanksi maupun upaya dalam penanggulangan pencemaran.
\end{abstract}

Kata Kunci: Pencemaran; Dinas Lingkungan Hidup; Peran.

\begin{abstract}
The condition of Brantas river in Surabaya is deteriorating as a result of contamination from household as well as industrial waste. As the provider of water for municipal fresh water supply service, the quality of Brantas river must be considered so as not to cause harm to the water users. The river part which is located in the downstream region makes the pollution even more severe. This condition is worsened by the lack of scrutiny and law enforcement efforts which ultimately also cause the degradation of the water quality of Brantas river. This study was performed to demonstrate the strategic role of the Environmental Office of Surabaya Municipality in controlling Brantas river water pollution in terms of the issuance of licenses, supervision, implementation of sanctions and measures taken to prevent water pollution.
\end{abstract}

Keywords: Pollution; Environmental Agencies; Role. 


\section{PENDAHULUAN}

Pencemaran bergantung pada keadaan alam, keadaan medan atau jelasnya dipengaruhi dan ditentukan oleh keadaan geografis suatu wilayah. ${ }^{1}$ Surabaya sebagai kawasan hilir memiliki banyak permasalahan yang harus segera ditangani untuk mengurangi pencemaran air Sungai Brantas sehingga kualitas air tetap terjaga. Hal ini karena air sungai Brantas merupakan bahan baku kehidupan seluruh warga Surabaya. Permasalahan lingkungan nasional yang berupa pencemaran dan perusakan lingkungan dalam perkembangannya terus terjadi, bahkan cenderung semakin parah, terutama setelah era reformasi dan otonomi daerah. ${ }^{2}$ Selain sebagai penyedia bahan baku air (PDAM), sungai Brantas juga dimanfaatkan dalam bidang perikanan, olahraga, komunikasi dan rekreasi.

Berdasarkan Buku Laporan Status Lingkungan Hidup Daerah (SLHD) Provinsi Jawa Timur Tahun 2010 disebutkan bahwa Kota Surabaya sebagai wilayah hilir terjadi penurunan kualitas air dari tahun ke tahun yang diakibatkan dari pencemaran limbah domestik 50\%, 40\% dari limbah industri dan $10 \%$ dari limbah pertanian, peternakan dan lainnya. Hal tersebut sesuai dengan apa yang disampaikan oleh Kepala Sub Bidang Komunikasi Dinas Lingkungan Hidup Provinsi Jawa Timur yakni, bahwa kondisi air sungai Brantas sekarang ini dalam status waspada karena pencemaran air sungai Brantas makin hari makin mengkawatirkan terutama yang menjadi faktornya adalah limbah domestik, yakni limbah rumah tangga.

Salah satu permasalahan pembangunan di Surabaya adalah pencemaran air dan tanah yang disebabkan oleh industri dan kegiatan/usaha serta limbah rumah tangga. Jumlah industri baik skala besar maupun kecil yang melakukan aktivitas juga secara tidak langsung merupakan penyumbang limbah yang berbahaya bagi keberlangsungan hidup. Menurut hasil riset Ecoton dan National Institute Minamata Disease menunjukkan bahwa air, lumpur, kerang, ikan, dan ekosistem Kali Surabaya telah terkontaminasi merkuri, timbal, kadmium, tembaga dan besi dengan kadar yang melebihi ambang batas. ${ }^{3}$

Berdasarkan hasil pemantauan kualitas air kali yang ada di kota Surabaya pada tahun 2015, status mutu air kali Surabaya selama satu tahun pemantauan menunjukkan $13 \%$ berstatus memenuhi baku mutu, $87 \%$ berstatus cemar ringan. ${ }^{4}$ Status mutu air dinyatakan pada kondisi tercemar apabila mutu air tidak me-

\footnotetext{
Muhamad Erwin, Hukum Lingkungan Dalam Sistem Kebijaksanaan Pembangunan Lingkungan Hidup (Refika Aditama 2011) 38.

Muhammad Akib, Hukum Lingkungan Perspektif Global dan Nasional (Raja Grafindo Persada 2014) 7. Adi Trisnawati,dkk, 'Analisis Kualitas dan Strategi Pengendalian Pencemaran Air Kali Surabaya' (2013) Jurnal Purifikasi 90, 91.

4 http://kotasurabaya.silh.menlh.go.id/pencemaran-air/diakses pada tanggal 5 Desember 2016.
} 
menuhi baku mutu air. Standar baku mutu air berbeda-beda disesuaikan dengan tujuan dari penggunaan air tersebut. Baku mutu adalah ambang batas kadar maksimum suatu zat atau bahan yang diperbolehkan berada di lingkungan agar tidak menimbulkan dampak negatif.

Dinas Lingkungan Hidup Kota Surabaya telah melakukan berbagai upaya dalam menanggulangi permasalahan pencemaran dan perusakan lingkungan, khususnya untuk menjaga kualitas sungai Brantas melalui perizinan dan pengawasan yang dilakukan secara periodik. Namun, pada kenyataannya tindakan preventif yang dilakukan, tidak banyak berdampak pada perbaikan kualitas air di sungai Brantas. Justru dari tahun ke tahun kualitas air sungai Brantas cenderung menurun.

Dinas Lingkungan Hidup berkewajiban melakukan pengawasan dan pengendalian lingkungan hidup guna mewujudkan Surabaya yang bebas dari perusakan dan pencemaran lingkungan. Industri dan kegiatan/usaha yang menghasilkan limbah cair biasanya membuang limbah pada waktu tengah malam disaat petugas dari Dinas Lingkungan Hidup Kota Surabaya maupun masyarakat tidak melakukan pengawasan terhadap industri dan kegiatan/usaha tersebut.

Adanya penurunan kualitas air tersebut tentunya menyebabkan pencemaran yang berdampak pada lingkungan, menurunnya tingkat kesehatan masyarakat maupun makhluk hidup lainnya. Dampak negatif dari menurunnya kualitas lingkungan hidup baik karena terjadinya pencemaran atau terkurasnya sumber daya alam adalah timbulnya ancaman atau dampak negatif terhadap kesehatan, menurunnya nilai este-ika, kerugian ekonomi dan terganggunya sistem alami. ${ }^{5}$

UU No 32 Tahun 2009 Tentang Perlindungan dan Pengelolaan Lingkungan Hidup atau selanjutnya disebut UU PPLH mengatur 14 (empat belas) asas dalam perlindungan dan pengelolaan lingkungan hidup. Selain itu, UU PPLH juga telah mengatur sanksi yang diberikan bagi seseorang yang melakukan perbuatan tertentu dan berakibat pada kerusakan atau pencemaran lingkungan.

Pada tingkat daerah, pengendalian dan pengawasan lingkungan hidup dilaksanakan oleh Dinas Lingkungan Hidup. Berikut data penegakan hukum menurut BLH Provinsi Jawa Timur.

Tabel 1 Data Penegakan Hukum Lingkungan Jawa Timur

\begin{tabular}{llcccc}
\hline NO & \multicolumn{1}{c}{ URAIAN } & SATUAN & $\mathbf{2 0 1 2}$ & $\mathbf{2 0 1 3}$ & $\mathbf{2 0 1 4}$ \\
\hline 1. & Sanksi Administrasi & Industri & 5 & 8 & 2 \\
2. & Proses/Sanksi Pidana & Industri & 6 & 4 & 4 \\
\hline
\end{tabular}

Takdir Rahmadi, Hukum Lingkungan di Indonesia (Raja Grafindo Persada 2014) 3. 
Sebagai instansi pelaksana otonomi daerah, Dinas Lingkungan Hidup Kota Surabaya mempunyai tugas, pokok dan fungsi untuk melaksanakan pengendalian dan pengawasan lingkungan, penanggulangan dampak lingkungan dan pemulihan dampak lingkungan. Tugas pokok dan fungsi tersebut mempunyai arti penting dalam mewujudkan pembangunan kota yang berwawasan lingkungan. Dalam penelitian ini akan mengulas mengenai peran Dinas Lingkungan Hidup Kota Surabaya dalam pengendalian pencemaran air sungai Brantas di Surabaya.

Lima faktor penyebab timbulnya masalah lingkungan, yakni teknologi, penduduk, ekonomi, politik dan tata nilai yang berlaku. ${ }^{6}$ Faktor pencemaran dan perusakan lingkungan hidup di Surabaya disebabkan oleh pertama, banyaknya kawasan industri, seperti di Margomulyo, Tandes, Rungkut dan sebagainya. Industri tersebut banyak berkontribusi dalam pencemaran air dan udara. Kedua, home industry yang tidak memiliki instalasi pengelolaan air limbah (IPAL) yang juga memberikan dampak berbahaya bagi kualitas air. Ketiga, banyaknya pembangunan di wilayah Surabaya, mulai dari hotel, apartemen, rumah sakit hingga rumah makan yang tentunya menghasilkan limbah.

Berdasarkan permasalahan yang telah uraian di atas, maka isu hukum yang akan dibahas yakni (1) bagaimana peran Dinas Lingkungan Hidup kota Surabaya sebagai lembaga pelaksana otonomi daerah dalam pengendalian pencemaran sungai Brantas Surabaya? (2) Apa upaya yang dilakukan dalam penanggulangan dampak pencemaran sungai Brantas Surabaya?

\section{Peran Dinas Lingkungan Hidup dalam Pengendalian Pencemaran Sungai Brantas Surabaya}

Air memiliki pengaruh dan arti penting dalam kehidupan sehari-hari. Selain digunakan secara konvensional, air juga digunakan untuk meningkatkan kualitas hidup manusia. Oleh karena itu pemanfaatan air harus sesuai dengan kebutuhan dan tidak mengganggu keseimbangan lingkungan lainnya. Air dinyatakan tercemar apabila air tidak dapat berfungsi sebagaimana mestinya yang diakibatkan oleh kegiatan atau aktivitas manusia. Disadari atau tidak bahwa manusia sebagai pelaku pencemaran dan/atau kerusakan lingkungan sekaligus sebagai korban dari pencemaran dan/atau kerusakan lingkungan itu sendiri.

Indikator atau tanda bahwa air telah tercemar adalah adanya perubahan atau tanda yang dapat diamati melalui: a) adanya perubahan suhu air; b) adanya perubahan $\mathrm{pH}$ atau konsentrasi ion Hidrogen; c) adanya perubahan warna, bau dan rasa air; d) timbulnya endapan, koloidal, bahan terlarut; e) adanya mikroorganisme; dan f) meningkatnya radioaktivitas air lingkungan. ${ }^{7}$ Air minum yang layak

\footnotetext{
Ibid.

Wisnu Arya Wardhana, Dampak Pencemaran Lingkungan (ANDI 2001) 74.
} 
dikonsumsi oleh manusia sesuai dengan ketetapan pemerintah adalah tidak berbau, tidak berasa, jumlah zat pada yang terlarut maksimal 1000 mg/liter, kekeruhan 5 NTU (Nephelometric Turbidity Units), dan warna maksimal 15 TCU (True Color Units). Sedang air bersih untuk mandi dan mencuci harus memenuhi kriteria sebagai berikut: tidak berbau, tidak berasa, jumlah zat oada terlarut maksimal 1500 mg/liter, kekeruhan 25 NTU dan warna maksimal 50 TCU. Pencemaran dapat menurunkan kualitas air sehingga tidak memenuhi standar air sehat. Namun dampak langsung dari pencemaran tidak dapat segera dirasakan oleh pengguna air. ${ }^{8}$

Dinas Lingkungan Hidup Kota Surabaya sebagai pelaksana urusan pemerintahan di bidang lingkungan hidup bertugas untuk melestarikan lingkungan hidup yang meliputi penataan, pemanfaatan, pengembangan, pemeliharaan, pemulihan pengawasan dan pengendalian lingkungan hidup. Struktur organisasi Dinas Lngkungan Hidup Kota Surabaya terbagi menjadi 3 (tiga) bidang yang mempunyai tugas melaksanakan sebagian tugas Dinas Lingkungan Hidup Kota Surabaya. 3 (tiga) bidang tersebut antara lain:

1. Bidang Penataan dan Peningkatan Kapasitas lingkungan Hidup, yang membawahi:

a. Seksi Pembinaan dan Peningkatan Kapasitas Lingkungan Hidup b. Seksi Pengawasan dan Penataan Hukum Lingkungan Hidup

2. Bidang Pengendalian Pencemaran dan Kerusakan Lingkungan Hidup, yang membawahi:

a. Seksi Pencegahan dan Pengendalian Lingkungan Hidup

b. Seksi Penanggulangan dan Pemulihan Pencemaran Lingkungan Hidup

3. Bidang Tata Lingkungan, yang membawahi:

a. Seksi Inventarisasi dan Penataan Lingkungan Hidup

b. Seksi Kajian Dampak Lingkungan Hidup.

Ketiga bidang tersebut mempunyai tugas dan fungsi guna melakukan pencegahan dan pengawasan. Tindakan pencegahan pencemaran dan/atau kerusakan lingkungan oleh Dinas Lingkungan Hidup Kota Surabaya dilakukan melalui penerbitan izin lingkungan yang menjadi syarat untuk memperoleh izin usaha/kegiatan.

Tujuan pengeluaran dan pengawasan izin ialah untuk mengendalikan lingkungan secara baik serta meningkatkan ketaatan pelaku usaha/kegiatan terhadap pencemaran dan/atau kerusakan lingkungan. Berkaitan dengan penerbitan izin lingkungan dan pengawasan pengelolaan lingkungan hidup, seorang pejabat dapat diancam pidana apabila yang bersangkutan tidak menjalankan sesuai dengan peraturan perundang-undangan. Hal ini merupakan upaya pence-

Muklis Akhadi, Isu Lingkungan Hidup - Mewaspadai Dampak Kemajuan Teknologi dan Polusi Lingkungan Global yang Mengancam Kehidupan (Graha Ilmu 2014) 279. 
gahan terjadinya pencemaran dan/ atau perusakan lingkungan hidup yakni dengan penerapan perizinan lingkungan, yang merupakan penegakan hukum administrasi untuk mewujudkan pembangunan berkelanjutan atau kegiatan usaha yang berwawasan lingkungan. ${ }^{9}$

Selain itu, Dinas Lingkungan Hidup kota Surabaya menerima dan menindaklanjuti pengaduan yang disampaikan oleh masyarakat. Pengaduan dugaan pencemaran dan/atau kerusakan sungai dapat disampaikan secara lisan maupun tertulis. Pengaduan secara lisan dapat dilakukan dengan cara mengadu langsung kepada Dinas Lingkungan Hidup Kota Surabaya maupun melalui telepon. Sedangkan pengaduan secara tertulis dapat disampaikan melalui surat, fax, pesan singkat maupun media. Setelah mendapatkan pengaduan dari masyarakat, Dinas Lingkungan Hidup Kota Surabaya melakukan rapat untuk penelaahan kasus, melakukan verifikasi lapangan, rekomendasi tindak lanjut serta menyampaikan perkembangan dan hasil dari tindak lanjut verifikasi yang telah dilakukan.

Berdasarkan pada Perwali Surabaya No. 74 Tahun 2016 Tentang Izin Lingkungan, Izin yang telah dikeluarkan dapat dibatalkan apabila:

a. Persyaratan yang diajukan dalam permohonan izin mengandung cacat hukum, kekeliruan, penyalahgunaan, serta ketidakbenaran dan/atau pemalsuan data, dokumen, dan/ atau informasi;

b. Penerbitannya tanpa memenuhi syarat sebagaimana tercantum dalam keputusan komisi tentang kelayakan lingkungan hidup atau rekomendasi UKL-UPL; atau

c. Kewajiban yang ditetapkan dalam dokumen AMDAL atau UKL-UPL tidak dilaksanakan oleh penanggung jawab usaha dan/atau kegiatan.

Berdasarkan pada Perwali tersebut di atas, maka setiap usaha dan/ atau kegiatan yang wajib memiliki AMDAL atau UKL-UPL wajib memiliki izin lingkungan. Izin lingkungan sangat diperlukan guna perlindungan pengelolaan lingkungan hidup yang merupakan syarat agar setiap kegiatan/usaha dapat melakukan kegiatan/usahanya. Melalui perizinan, maka Dinas Lingkungan Hidup Kota Surabaya memiliki kewenangan dalam melakukan pengendalian dan pengawasan terhadap pelaku usaha yang telah memperoleh izin usaha agar tetap taat pada aturan yang berlaku. Apabila didalam kegiatan pengendalian dan pengawasan tersebut pemegang izin melakukan pelanggaran, maka Dinas Lingkungan Hidup dapat menerapkan sanksi administratif.

Sanksi tersebut antara lain teguran tertulis apabila industri dan usaha/kegiatan tidak memiliki izin lingkungan maupun tidak melaksanakan kewajiban sebagai pemegang izin.

Syamsul Arifin, Hukum Perlindungan dan Pengelolaan Lingkungan Hidup di Indonesia (Sofmedia 2012) 200. 
Apabila teguran tertulis tersebut tidak diindahkan, maka sanksi berikutnya ialah paksaan pemerintah yang dapat berupa penghentian sementara kegiatan produksi, pemindahan sarana produksi, penutupan saluran pembuangan air limbah atau emisi dan pembongkaran, penyitaan barang atau alat yang berpotensi menimbulkan pelanggaran, penghentian sementara seluruh kegiatan hingga tindakan lain dengan tujuan untuk menghentikan pelanggaran dan tindakan memulihkan fungsi lingkungan hidup.

Apabila paksaan pemerintah tetap tidak dilaksanakan atau melakukan kegiatan lain selain yang tercantum dalam izin lingkungan, maka Dinas Lingkungan Hidup dapat melakukan pembekuan izin. Dinas Lingkungan Hidup juga dapat melakukan pencabutan izin lingkungan apabila penanggungjawab industri dan kegiatan/ usaha memindahtangankan izin usahanya kepada pihak lain dan tidak melaksanakan paksaan pemerintah serta apabila dari kegiatan/usaha tersebut secara nyata telah menyebabkan perusakan atau pencemaran lingkungan yang dapat merugikan orang lain.

Penegakan hukum administrasi dianggap sebagai upaya penegakan hukum terpenting. Hal ini karena penegakan hukum administrasi lebih ditujukan kepada upaya mencegah terjadinya pencemaran dan perusak- an lingkungan. Disamping itu, penegakan hukum administrasi juga bertujuan untuk menghukum pelaku pencemaran dan perusakan lingkungan. ${ }^{10}$

Meskipun telah ada aturan hukum yang mengatur tentang lingkungan hidup ternyata bukan jaminan menjadikan sungai Brantas Surabaya bebas dari pencemaran. Dari hasil uji laboratorium Dinas Lingkungan Hidup, air bersih Kota Surabaya yang masih memenuhi baku mutu pada tahun 2007 mencapai 93,6\% dan pada tahun 2008 mencapai $97,5 \%$ sedangkan pada tahun 2009 air bersih yang masih memenuhi baku mutu hanya mencapai 58,2\%". ${ }^{11} \mathrm{Hal}$ ini menunjukkan bahwa dari tahun ke tahun pencemaran air di sungai Brantas semakin meningkat dikarenakan beban pencemaran pun meningkat.

Perizinan menjadi salah satu masalah yang banyak memberi peluang bagi berkembangnya masalah lingkungan dibandingkan dengan membatasinya. ${ }^{12}$ Seperti yang telah diuraikan sebelumnya, bahwa Dinas Lingkungan Hidup memiliki peran stategis dalam pencegahan perusakan atau pencemaran lingkungan, baik melalui perizinan maupun pengawasan. Namun, saat ini masih ada industri dan kegiatan/usaha yang tidak dilengkapi dengan izin lingkungan tetapi masih dapat melakukan aktivitas usa-

\footnotetext{
Sukanda Husin, Penegakan Hukum Lingkungan Indonesia (Sinar Grafika 2009) 92. http://lh.surabaya.go.id/weBLH KOTA SURABAYA Kota Surabaya/index.php? c=main\& m= pencemaran diakses pada tanggal 5 Desember 2016.

12 Muhamad Erwin, Op.Cit 121.
} 
ha yang diperparah dengan pembiaran atas pelanggaran tersebut.

Pembiaran pelanggaran dilakukan dengan alasan kedudukan Dinas Lingkungan Hidup tingkat kota tidak memiliki kewenangan yang cukup untuk dapat menjatuhkan sanksi kepada pelaku pencemar dan/atau perusak lingkungan. Prapenyidikan dilakukan oleh Dinas Lingkungan Hidup, penyidikan dilakukan oleh polisi sedangkan penuntutan dilakukan oleh Jaksa dimana antara Polisi dan Jaksa bukan merupakan pejabat khusus yang menangani kasus lingkungan.

Berbeda hal nya dengan di negara lain, seperti Australia yang memiliki Environmental Protection Act (EPA) dan di Belanda yang memiliki Environmental Management Act (EMA) yang mempunyai wewenang menginvestigasi seseorang yang diduga merusak lingkungan hidup, dapat menjatuhkan denda atas pelanggarannya. Mempunyai tiga kewenangan sekaligus seperti kewenangan pengaturan (legilasi), kepolisian, dan pengadilan. ${ }^{13} \mathrm{Hal}$ inilah yang menjadikan kelemahan dalam penegakan hukum lingkungan yang berakibat pada kualitas baku mutu sungai Brantas semakin menurun.

UU PPLH mengatur tentang Pejabat Pengawas Lingkungan Hidup atau yang disebut dengan PPLH yang mempunyai kewenangan dalam pengawasan hingga penghentian kegiatan usaha. Pengawasan oleh PPLH untuk menge- tahui, memastikan dan menetapkan tingkat ketaatan penanggung jawab usaha dan/atau kegiatan atas ketentuan yang ditetapkan dalam izin lingkungan dan peraturan perundangundangan di bidang perlindungan dan pengelolaan lingkungan hidup. ${ }^{14}$ Namun, kehadiran PPLH tersebut tidak banyak membantu dalam mengurangi perusakan atau pencemaran lingkungan di sungai Brantas Surabaya.

Dinas Lingkungan Hidup Kota Surabaya telah bekerjasama dengan berbagai instansi pemerintahan lainnya, institusi pendidikan, LSM maupun masyarakat dalam melaksanakan pengawasan dan pengandalian. Dengan harapan agar masalah pencemran dan/atau perusakan lingkungan dapat segera ditangani sehingga masyarakat dapat memperoleh perlindungan untuk memperoleh hak lingkungan hidup yang sehat dan bersih.

Terbentuknya Tim Patroli Air, yakni organisasi lingkungan yang menangani masalah pencemaran yang terjadi di sungai Brantas Surabaya dengan tugas untuk melakukan patroli air disepanjang sungai Brantas, melakukan pelatihan atau pendampingan kepada warga di bantaran sungai untuk merubah perilaku yang dapat merusak atau pencemaran lingkungan serta melakuan pelatihan kader lingkungan bagi pelajar di Surabaya.

Upaya lainnya dalam mencari solusi dalam mengatasi pencemaran ling-

Adrian Sutedi, Hukum Perizinan Dalam Sektor Pelayanan Publik (Sinar Grafika 2011) 247.

14 Hamrat Hamid dan Bambang Pramudyanto, Pengawasan Industri Dalam Pengendalian Pencemaran Lingkungan (Granit 2007) 21. 
kungan, antara lain melakukan uji emisi kendaraan umum maupun kendaraan pribadi bekerjasama dengan Dinas Perhubungan guna mengurangi pencemaran. Car free day yang dilakukan tiap hari Minggu dan telah ada 6 (enam) lokasi car free day di Surabaya yakni J1 Raya Darmo, J1 Tunjungan, J1 Kertajaya, J1 Jimerto, J1 Jemur Andayani dan J1 Kembang Jepun. Hal ini di lakukan sebagai upaya untuk mengurangi gas emisi karbon kendaraaan, untuk menciptakan udara kota Surabaya bersih dan bebas dari pencemaran.

Selain itu Dinas Lingkungan Hidup juga membuat program Kampung Green and Clean, yakni dengan perlombaan antar kampung sehingga mendorong tiap kampung di Surabaya menjadi bersih dan hijau, baik melalui penanaman tanaman maupun pengolahan sampah rumah tangga. Selain merangkul kampung, Dinas Lingkungan Hidup kota Surabaya juga mengajak institusi pendidikan SD hingga Perguruan Tinggi untuk sadar akan lingkungan. Salah satunya ialah melalui program Eco Campus yang telah terselenggara mulai tahun 2010 dengan tujuan agar sivitas akademika berpartisipasi dan melakukan berbagai inovasi lingkungan hidup.

Kriteria penilaian program Eco Campus antara lain: penerapan visi misi institusi yang mengarah pada Eco Campus; adanya kebijakan kampus tentang pelaksanaan kegiatan bertema lingkungan hidup; adanya kebijakan kampus dalam upaya efisiensi penggunaan air, listrik, ATK dll; adanya kebijakan kampus tentang terciptanya lingkungan kampus yang bersih dan sehat; adanya kebijakan kampus untuk merencanakan kegiatan dan mengalokasikan anggaran bagi kegiatan lingkungan hidup; pemanfaatan sarana dan prasarana untuk pengelolaan limbah cair dan padat hingga upaya pengelolaan kantin dan makanan yang sehat.

\section{Upaya Penanggulangan Dampak Pencemaran Sungai Brantas Surabaya}

Berdasarkan pada hasil penelitian yang telah dilakukan, teridentifikasi bahwa parameter pencemar air kali Surabaya adalah TSS, BOD, DO, Nitrit, Minyak dan Fenol. Teridentifikasi bahwa status mutu air kali Surabaya tergolong tercemar ringan. Prioritas strategi pengendalian pencemaran adalah ketegasan dalam rangka menaati peraturan perundang-undangan yang artinya memberikan sanksi terhadap siapa saja pelanggar peraturan. ${ }^{15}$

Upaya penanggulangan dampak pencemaran sungai Brantas dapat dilakukan dengan berbagai model pendekatan. Salah satunya ialah dengan menggunakan pendekatan command and control (CAC) approach atau pendekatan atur dan awasi. ${ }^{16}$ CAC approach ini menekankan pada upaya pencegahan pencemaran melalui izin yang menetapkan persyaratanpersyaratan lingkungan hidup yang

\footnotetext{
Adi Trisnawati,Op.Cit 90, 98.

16 Sukanda Husin, Penegakan Hukum Lingkungan di Indonesia (Sinar Grafika 2009) 140.
} 
disebut dengan command approach dan diikuti dengan suatu sistem pengawasan agar penataan dapat dijamin yang disebut dengan control approach.

Pengawasan memegang posisi sentral, karena melalui pengawasan dapat dilakukan pembinaan agar penanggungjawab usaha/kegiatan patuh kepada peraturan dan persyaratan izin yang telah diberikan. Jika dari hasil pengawasan ternyata terdapat pelanggaran yang tidak dapat ditoleransi lagi, maka harus segera diambil tindakan hukum agar dampaknya tidak meluas. ${ }^{17}$ Pada saat ini, masyarakat mengharapkan agar pejabat di bidang perizinan bersih, penegakan hukum yang bebas dari Korupsi, Kolusi dan Nepotisme (KKN).

Pengawasan oleh Dinas Lingkungan Hidup Kota Surabaya berdasarkan Pasal 46 PP No 82 Tahun 2001 Tentang Pengelolaan Kualitas Air dan Pengendalian Pencemaran Air, yakni:

a. Melakukan pemantauan yang meliputi pengamatan, pemotretan, perekaman audio visual, dan pengukuran;

b. Meminta keterangan kepada masyarakat yang berkepentingan, karyawan yang bersangkutan, konsultan, kontraktor, dan perangkat pemerintahan setempat;

c. Membuat Salinan dari dokumen dan atau membuat catatan yang diperlukan, antara lain dokumen perizinan, dokumen AMDAL, UKL, UPL, data hasil swapantau, dokumen surat keputusan organisasi perusahaan;

d. Memasuki tempat tertentu;

e. Mengambil contoh dari air limbah yang dihasilkan, air limbah yang dibuang, bahan baku, dan bahan penolong;

f. Memeriksa peralatan yang digunakan dalam proses produksi, utilitas, dan instalasi pengelolaan limbah;

g. Memeriksa instalasi, dana atau alat transportasi;

h. Serta meminta keterangan dari pihak yang bertanggungjawab atas usaha dana atau kegiatan.

Berbagai upaya dilakukan guna mengurangi kerusakan atau pencemaran lingkungan, namun belum dapat mengubah status mutu air Sungai Brantas yang telah tercemar. Hal ini dikarenakan lemahnya penegakan hukum bagi pelaku perusakan atau pencemaran sungai Brantas Surabaya sehingga tidak dapat berjalan efektif. Ada beberapa faktor yang mempengaruhi lemahnya penegakan hukum, antara lain Faktor hukumnya sendiri;

1. Faktor penegak hukum;

2. Faktor sarana atau fasilitas pendukung penegakan hukum;

3. Faktor masyrakat; dan

4. Faktor kebudayaan. ${ }^{18}$

Selain faktor-faktor tersebut di atas, ada pula faktor lain yang mem-

Muhammad Akib, Op.Cit 64.

18 Syahrul Machmud, Penegakan Hukum Lingkungan Indonesia-Penegakan Hukum Administrasi, Hukum Perdata, dan Hukum Pidana Menurut Undang-Undang No.32 Tahun 2009 (Graha Ilmu 2012) 265. 
pengaruhi lemahnya penegakan hukum lingkungan di Indonesia, antara lain ${ }^{19}$ :

a. Proses pengumpulan bahan keterangan (prapenyelidikan), penyidikan dan penuntutan dilakukan oleh instansi yang berbeda-beda dengan kemampuan koordinasi yang sangat lemah. Bahan keterangan biasanya dilakukan oleh Dinas Lingkungan Hidup, penyidikan oleh Polisi, penuntutan oleh Jaksa. Polisi dan Jaksa bukan khusus menangani kasus lingkungan. Koordinasi diantaranya sangat memakan waktu, apalagi persepsi yang dimiliki masing-masing berbeda.

b. Tidak dikenalnya lembaga expert judge (Hakim Ad Hoc) yaitu seorang ahli lingkungan yang berperan sebagai anggota Majelis Hakim untuk mengatasi kewenangan Hakim di bidang hukum lingkungan.

c. Belum adanya pedoman penegakan hukum dan penataan lingkungan yang dapat dijadikan acuan bagi apparat penegak hukum.

d. Akses masyarakat terhadap informasi status penataan suatu kegiatan masih tertutup. Jaminan ini dapat menjadikan peran masyarakat dan organisasi lingkungan sebagai pengawas eksternal yang efektif dari proses penegakan hukum pidana lingkungan.

e. Integritas lembaga peradilan.

Penegakan hukum lingkungan adalah pengawasan dan penerapan (atau dengan ancaman) penggunaan instrumen administratif, kepidanaan, atau keperdataan untuk mencapai penataan ketentuan hukum dan peraturan yang berlaku umum dan individu. ${ }^{20}$ Setiap tindakan atau kegiatan yang berdampak pada lingkungan dan menimbulkan kerugian bagi orang lain patut diberi sanksi tanpa ada pembedaan antara industri kecil maupun besar. Setiap orang tidak kebal hukum, artinya siapapun yang secara sengaja maupun tidak sengaja melakukan tindakan yang berdampak pada lingkungan, maka patut untuk mempertanggungjawabkan perbuatannya tersebut.

Hadirnya Perda No 2 Tahun 2008 Tentang Pengelolaan Kualitas Air dan Pengendalian Pencemaran Air di Provinsi Jawa Timur dirasa sudah tidak sesuai dengan kondisi saat ini. Kelemahan dari Perda tersebut antara lain tidak adanya kebijakan progresif, artinya kehadiran Perda tersebut tidak bisa merubah kondisi pencemaran lingkungan yang semakin parah. Perda tersebut juga belum mampu menjawab persoalan dalam pengelolaan air dan pengendalian pencemaran air. masalah kualitas air dan tingginya pencemaran sama sekali belum terjawab dalam Perda tersebut.

Penegakan hukum lingkungan di Indonesia mencakup penataan dan penindakan (compliance and enforcement). ${ }^{21}$ Penataan merupakan upaya penegakan hukum secara preventif

Ibid 264.

20 Supriadi, Hukum Lingkungan Indonesia (Sinar Grafika 2008) 267. 
yakni untuk mencegah terjadinya perusakan atau pencemaran lingkungan dengan patuh pada aturan perundangundangan yang telah ditetapkan. Termasuk pada penataan ialah hukum administrasi. Sedangkan penindakan merupakan upaya penegakan hukum secra represif yakni pemberian sanksi bagi pelaku perusak atau pencemar lingkungan. Hukum perdata dan hukum pidana merupakan bentuk dari penindakan. Penegakan hukum administrasi di bidang lingkungan untuk pencegahan terjadinya perusakan atau pencemaran lingkungan, sedangkan penegakan hukum perdata dan pidana bertujuan untuk pemulihan lingkungan serta memberi sanksi kepada pelaku perusakan atau pencemaran lingkungan.

UU PPLH mengenal asas ultimum remedium, yakni penerapan penegakan hukum pidana sebagai pilihan hukum yang terakhir. Penerapan hukum pidana disandarkan pada keadaan sanksi administratif yang telah dijatuhkan tidak dipatuhi, atau pelanggaran dilakukan lebih dari satu kali. $^{22}$ Pada asas ini, hanya diberlakukan pada delik formal tertentu, bukan terhadap seluruh delik formal.

Upaya penanggulangan dampak pencemaran lingkungan yang dapat diterapkan untuk meminimalisasi pencemaran lingkungan sungai Brantas Surabaya, antara lain:

$21 \quad$ Muhammad Akib, Op.Cit 204.

22 So Woong Kim, 'Kebijakan Hukum Pidana Dalam Upaya Penegakan Hukum Lingkungan Hidup' (2013) Jurnal Dinamika Hukum, 415,427.

23 Muhammad Akib, Penegakan HukumLingkungan dalam Perseptif Holistik-Ek ologis (Graha Ilmu 2015$) 64$.

24 Wisnu Arya Wardhana, Op.Cit 160. a. Perumusan hukum dan kebijakan lingkungan yang berpihak pada kepentingan lingkungan;

b. Penerapan secara benar instrumen RPPLJ, KLHS, perizinan lingkungan, baku mutu lingkungan, AMDAL dan sebagainya;

c. Reformasi birokrasi pemerintah daerah, khususnya yang berkaitan dengan pelayanan publik di bidang lingkungan hidup atau yang berdampak pada lingkungan; dan

d. Memperkuat wewenang dan kelembagaan. ${ }^{23}$

Penanggulangan pencemaran air sungai Brantas dapat dilakukan secara non-teknis dan secara teknis. Non-teknis, yaitu suatu usaha untuk mengurangi dan mananggulangi pencemaran lingkungan dengan cara menciptakan peraturan perundang-undangan yang dapat merencanakan, mengatur dan mengawasi segala macam bentuk kegiatan industri dan teknologi sedemikian rupa sehingga tidak terjadi pencemaran lingkungan. Sedangkan upaya penanggulangan secara teknis dapat dilakukan dengan mengelola limbah dengan cara pengolahan awal, pengolahan lanjutan dan pengelolaan akhir. ${ }^{24}$

Pengolahan awal (Primary Waste Treatment) merupakan tahap awal dalam pemisahan antara bahan buangan yang masih dapat di daur ulang dan bahan buangan yang sudah tidak dapat di daur ulang. Jika berupa limbah cair, maka pengolahan awal dila- 
kukan dengan cara mengendapkan limbah cair tersebut sehingga dapat dipisahkan antara limbah cair yang bisa langsung dibuang di sungai dengan limbah cair yang memerlukan pengolahan pada tahap berikutnya.

Tahap kedua ialah pengolahan lanjutan (Secondary Waste Treatment) yakni memasukkan mikroorganisme kedalam limbah cair dengan maksud untuk mendegradasi bahan buangan. Tahap ketiga ialah pengolahan tahap akhir (Advanced Waste Treatment) yakni tahapan terakhir dalam pengelolaan limbah sehingga limbah sudah dapat dibuang di sungai atau lingkungan lainnya.

Besarnya biaya pengelolaan limbah inilah yang menjadi salah satu faktor pelaku usaha/kegiatan lebih memilih untuk membuang limbah secara langsung ke sungai tanpa diolah terlebih dahulu. Akibatnya, sungai menjadi tercemar dan menimbulkan kerugian bagi masyarakat lainnya. Oleh karena itu, pengawasan Dinas Lingkungan Hidup secara rutin perlu terus dilakukan. Selain itu partisipasi masyarakat dalam melakukan pelaporan atas dugaan pencemaran lingkungan juga cukup membantu Dinas Lingkungan Hidup dalam menanggulangi pencemaran sungai Brantas Kota Surabaya.

Partisipasi masyarakat juga mendukung dalam penanggulangan pencemaran lingkungan. Pasal 65 ayat (5) UU PPLH menyatakan bahwa setiap orang berhak melakukan pengaduan akibat dugaan pencemaran dan/atau perusakan lingkungan hidup. Artinya ketika terjadi dugaan pencemaran dan/atau kerusakan sungai Brantas, masyarakat dapat melakukan pengaduan kepada Dinas Lingkungan Hidup Kota Surabaya agar dapat ditindaklanjuti dan hal ini merupakan salah satu upaya dalam pencegahan pencemaran sungai Brantas.

\section{PENUTUP}

Dari pembahasan yang telah diuraikan di atas, maka dapat disimpulkan bahwa sesungguhnya peran Dinas Lingkungan Hidup Kota Surabaya dalam pencegahan dan penanggulangan pencemaran air sungai Brantas di Surabaya sangat penting. Namun yang menjadi kendala sampai dengan saat ini, ialah lemahnya penegakan hukum lingkungan (administrasi, perdata, maupun pidana) yang disebabkan karena proses prapenyidikan, penyidikan dan penuntutan dilakukan oleh berbagai instansi yang berbeda tidak hanya dilakukan oleh Dinas Lingkungan Hidup.

Peran Dinas Lingkungan Hidup antara lain penerbitan izin lingkungan, melakukan pengawasan serta menindaklanjuti atas pengaduan secara tertulis maupun lisan. Namun, perlu adanya reformasi kelembagaan dengan mempertegas kewenangan Dinas Lingkungan Hidup yang saat ini hanya bersifat koordinatif. Selain itu perlu adanya reformasi aparatur sehingga dapat meningkatkan integritas dan kemampuan para aparat hukum, baik Dinas Lingkungan Hidup dalam kapasitasnya untuk menerbitkan izin, 
Polisi dalam melakukan penyidikan, Jaksa dalam melakukan penuntutan maupun Hakim dalam memutus perkara pencemaran dan/atau kerusakan lingkungan.

\section{DAFTAR BACAAN}

\section{Buku:}

Akhadi, Mukhlis, Isu Lingkungan Hidup - Mewaspadai Dampak Kemajuan Teknologi dan Polusi Lingkungan Global yang Mengancam Kehidupan (Graha Ilmu 2014).

Akib, Muhammad, Hukum Lingkungan Perspektif Global dan Nasional (RajaGrafindo Persada 2014).

Arifin, Syamsul, Hukum Perlindungan dan Pengelolaan Lingkungan Hidup di Indonesia (Sofmedia 2012).

Erwin, Muhamad, Hukum Lngkungan Dalam Sistem Kebijaksanaan Pembangunan Lingkungan Hidup (Refika Aditama 2011).

Hamid, Hamrat dan Pramudyanto, Bambang, Pengawasan Industri Dalam Pengendalian Pencemaran Lingkungan (Granit 2007).

Husin, Sukanda, Penegakan Hukum Lingkungan Indonesia (Sinar Grafika 2009).

Machmud, Syahrul, Penegakan Hukum Lingkungan Indonesia-Penegakan Hukum Administrasi, Hukum Perdata, dan Hukum Pidana Menurut UndangUndang No. 32 Tahun 2009 (Graha Ilmu 2012).
Rahmadi, Takdir, Hukum Lingkungan di Indonesia (RajaGrafindo Persada 2014).

Supriadi, Hukum Lingkungan Indonesia (Sinar Grafika 2008).

Sutedi, Adrian, Hukum Perizinan Dalam Sektor Pelayanan Publik (Sinar Grafika 2011).

Taufik M, Mohammad, Aspek-aspek Hukum Lingkungan (Indeks 2011).

Wardhana, Wisnu Arya, Dampak Pencemaran Lingkungan (ANDI 2001).

Zulkifli, Arif, Dasar-dasar Imu Lingkungan (Salemba 2014).

\section{Jurnal:}

Trisnawati, Adi. dkk, Analisis Kualitas dan Strategi Pengendalian Pencemaran Air Kali Surabaya (2013) 14 Jurnal Purifikasi.

So Woong Kim, Kebijakan Hukum Pidana Dalam Upaya Penegakan Hukum Lingkungan Hidup (2013) Jurnal Dinamika Hukum.

\section{Perundang-undangan:}

UU No 32 Tahun 2009 Tentang Perlindungan dan Pengendalian Lingkungan Hidup.

PP No 2 Tahun 2004 Tentang Pengelolaan Kualitas Air dan Pengendalian Pencemaran Air.

Peraturan Menteri Negara Lingkungan Hidup No. 09 Tahun 2010 Tentang Tata Cara Pengaduan dan Penanganan Pengaduan Akibat Dugaan 
Pencemaran dan/atau Perusakan Lingkungan Hidup.

Peraturan Daerah Kota Surabaya No. 14 Tahun 2016 Tentang Pembentukan dan Susunan Perangkat Daerah Kota Surabaya.

Peraturan Walikota Surabaya No. 74 Tahun 2016 Tentang Izin Lingkungan.

Peraturan Walikota Surabaya No. 58 Tahun 2016 Tentang Kedudukan, Susunan Organisasi, Uraian Tugas dan Fungsi Serta Tata Kerja Dinas Lingkungan Hidup Kota Surabaya. 
